\title{
Using viral vectors as gene transfer tools (Cell Biology and Toxicology Special Issue: ETCS-UK 1 day meeting on genetic manipulation of cells)
}

\author{
Joanna L. Howarth • Youn Bok Lee • \\ James B. Uney
}

Received: 30 June 2009 /Accepted: 24 September 2009 / Published online: 15 October 2009

(C) The Author(s) 2009. This article is published with open access at Springerlink.com

\begin{abstract}
In recent years, the development of powerful viral gene transfer techniques has greatly facilitated the study of gene function. This review summarises some of the viral delivery systems routinely used to mediate gene transfer into cell lines, primary cell cultures and in whole animal models. The systems described were originally discussed at a 1-day European Tissue Culture Society (ETCS-UK) workshop that was held at University College London on 1st April 2009. Recombinant-deficient viral vectors (viruses that are no longer able to replicate) are used to transduce dividing and post-mitotic cells, and they have been optimised to mediate regulatable, powerful, long-term and cell-specific expression. Hence, viral systems have become very widely used, especially in the field of neurobiology. This review introduces the main categories of viral vectors, focusing on their initial development and highlighting modifications and improvements made since their introduction. In particular, the use of specific promoters to restrict expression, translational enhancers and regulatory elements to boost expression from a single virion and the development of regulatable systems is described.
\end{abstract}

J. L. Howarth $(\bowtie) \cdot$ Y. B. Lee $\cdot$ J. B. Uney

Henry Wellcome Laboratories for Integrative Neuroscience and Endocrinology, University of Bristol,

Whitson Street,

Bristol BS1 3NY, UK

e-mail: j.howarth@bristol.ac.uk
Keywords Viral vectors · Gene therapy · Adenovirus · Lentivirus

\section{Gene transfer technology}

In 2004, the entire human genome was sequenced and over 25,000 genes were identified (Stein 2004). Some of these initially uncharacterised genes have subsequently been identified, with many playing important roles in cellular development, maintenance and survival. Techniques that allow the study of these novel genes have therefore been instrumental in elucidating their function. Until relatively recently, gene expression could only be altered in post-mitotic neuronal cells using mouse transgenesis or microinjection of individual neurons in culture. However, the first adenoviral and Herpes gene transfer systems were highly effective at transducing neurons and could hence be used to study gene function in whole animal systems without developmental compensatory effects (Hermens and Verhaagen 1998). Researchers were quick to see the potential of such systems and started to develop optimised vectors. An ideal gene delivery would: (1) transfer genes into both developing and mature animals; (2) transduce cells with high efficiency; (3) mediate high level, long-term expression; (4) cause limited cytotoxicity; (5) elicit a small/ negligible immune response in vivo; (6) incorporate sufficient lengths of DNA so that transgenes of interest can be accommodated and (7) mediate 
regulatable expression. These characteristics are difficult to find in a single vector system, and hence, a variety of viral gene delivery systems have been developed, each with its own advantages and disadvantages (Table 1).

\section{Herpes simplex virus}

Wild-type Herpes simplex virus (HSV) is a large double-stranded DNA virus that infects and replicates in the skin and mucous membranes. Due to the natural tropism of HSV, initial studies were performed on neurons (Ho and Mocarski 1988, 1989). Many studies have now demonstrated long-term stable transgene expression in the nervous system (Glorioso and Fink 2009), and preclinical studies on models of neurological disease, including glioma, peripheral neuropathy, chronic pain and neurodegeneration, show encouraging results (Cuchet et al. 2007). Wildtype HSV is taken up by sensory nerve terminals and transported by retrograde axonal transport to dorsal root ganglion neurons where they may enter the lytic cycle or establish a latent state from which the virus may subsequently reactivate and spread. The HSV vector systems therefore mimic this latent state, producing a highly infectious, efficient vehicle for the delivery of exogenous genetic material to cells. The straightforward production of high-titre, pure preparations of non-pathogenic HSV vectors, known as amplicon vectors (Cuchet et al. 2007), was achieved by introducing null mutations into viral immediate early genes. This readily disrupts the capacity for viral replication, but enables production of the vectors by in vitro complementation of these genes in trans. When used to transduce cells, these HSV vectors cause a latent-like infection in both neural and non-neural tissue. Further details on HSV vecterology can be found in reviews by Epstein et al. (Cuchet et al. 2007; Epstein 2005).

\section{Adeno-associated virus}

Adeno-associated viruses (AAV) are parvoviruses that require co-infection with another helper virus (either adenovirus or HSV) to mediate their replication. The small non-enveloped icosahedral virions (18- to 26-nm diameters) contain a single-stranded DNA molecule (4-5 kb) that contains inverted terminal repeats (ITR) which enable site-specific integration of wild-type AAV into chromosome 19 as well as allow secondary structure formation of the viral genome that aids viral DNA replication with host cell polymerase (Ni et al. 1998). The non-pathogenic and persistent long-term nature of AAV infection (Wright et al. 2003), combined with its wide range of infectivity, made this virus an important candidate as a therapeutic gene transfer vector. In addition, the relatively small cis-acting elements (the ITRs) in AAV vectors greatly reduce the risk of recombination with wild-type virus as well as the level of cellular immune response elicited, therefore improving the safety of this vector in human clinical applications (Koczot et al. 1973). Furthermore, AAV vectors have a broad host and cell type tropism transducing both dividing and non-dividing cells.

Table 1 Viral vector systems

\begin{tabular}{lllcccc}
\hline Vector & Entry & Immune response & Capacity $(\mathrm{kb})$ & Location & Ease of production & Expression \\
\hline Retrovirus (inc lentivirus) & Fusion & Minimal & 8 & Integrates & $10^{8 * *}$ & Years \\
Adenovirus & Receptor & Brisk*** & 36 & Episomal & $10^{12 * * * * *}$ & Weeks/months \\
AAV & Receptor & None & 4 & Integrates & $10^{8 * * *}$ & Years \\
HSV & Fusion & Brisk**** & 30 & Episomal & $10^{10 * * * *}$ & Weeks \\
\hline
\end{tabular}

The main characteristics of the four main viral vector systems being used to transfer genetic material into cells both in vitro and in vivo are compared above. Each system has been modified since their initial creation, enabling the capacity for the foreign transgene to be increase, especially in the case of adenoviral vectors where gutless vectors have a very large cloning capacity. The host immune response differs between each system, with retroviruses and AAV showing little or negligible immune response. In addition, these two systems facilitate long-term transgene expression. Adenoviral vectors have also shown increased longevity of transgene expression, especially when the promoter included in the viral cassette is modified from CMV

Asterisks indicate the relative ease of production or the relative level of immune response, i.e. a greater ease of production or greater immune response elicited is represented by a higher score 
The first infectious clone of AAV serotype 2 (AA2) was established in 1982. It was used to generate the first recombinant AAV (rAAV) vectors (Hermonat and Muzyczka 1984) and has therefore been studied in great detail, and many mechanisms involved in AAV integration and latency have been elucidated (Gao et al. 2002). AAV2 is widely used to transduce neurons as it demonstrates neuron-specific expression. However, more recently, multiple serotypes of wild-type AAV (12 human serotypes and more than 100 serotypes from nonhuman primates), each with a different targeting capacity, have now been identified (Daya and Berns 2008). Due to the diverse tissue tropisms and potential to evade preexisting antibodies against the common human AAV serotype 2, some of these AAV serotypes may have the potential to be developed as novel human gene therapy vectors (Coura and Nardi 2007). The use of the different AAV serotypes in a pseudotyping approach (the genome of one ITR serotype being packaged into a different serotype capsid) has allowed broad tissue tropisms, with greater gene expression being seen in muscle, retina, liver and heart (using AAV serotypes 1, 5, 8 and 9, respectively). Studies have also examined the transduction and expression characteristics of these serotypes in brain (Cearley et al. 2008), and AAV9 was shown to transduce a large number of cells with unique expression pattern. However, some tissues remain refractory to transduction using available serotypes, presenting a major challenge for AAVbased gene therapy in clinically relevant tissues. Two approaches have been employed: (1) altering the direct targeting of rAAV vectors by either the insertion of small peptides or ligands directly into the viral capsid sequence (e.g. aiding targeting of endothelial cells; Stachler and Bartlett 2006; White et al. 2004) or by site-directed, insertional mutagenesis of the AAV2 capsid (Muzyczka and Warrington 2005; Shi et al. 2001) and (2) using an associating molecule, such as a bispecific antibody (Bartlett et al. 1999) or biotin (Arnold et al. 2006) which interacts with both the viral surface and specific cell surface receptor and mediated indirect targeting. The latter approach enables the coupling of different adaptors to the capsid, ablating the native targeting and enhancing specific targeting without significantly changing the capsid structure.

Regardless of serotype, the production of rAAV vectors involves splitting the AAV genome between two plasmids: (1) a recombinant AAV vector plasmid where the AAV capsid genes are replaced with the gene of interest, bracketed by ITRs and (2) a nonrescuable AAV helper plasmid encoding AAV capsid proteins. The production of recombinant AAV vectors also requires a helper virus (adenovirus or HSV) which allows viral replication, and density gradient centrifugation is typically used to separate recombinant AAV vectors from the adenoviral or HSV helper.

The inclusion of ITRs in rAAV vector systems prevents integration into chromosome 19, and current rAAV vectors persist primarily as extrachromosomal elements (Afione et al. 1996; Schnepp et al. 2005). In addition, the small size of these vectors limits the insertion of gene expression cassettes, and gene expression is generally of slow onset due to the required conversion of the single-stranded AAV DNA into double-stranded DNA. Such limitations have been overcome by the generation of minimal expression cassettes and self-complementary AAV2 vectors, respectively. The latter enable the rate-limiting second-strand DNA synthesis to be bypassed, enhancing transduction of some organs and tissues such as liver (McCarty et al. 2001), muscle (Wang et al. 2003), brain (Fu et al. 2003) and retina (Yang et al. 2002). As a result, rAAV-based gene transfer vectors still represent one of the most promising gene therapy systems and gain increasing popularity. rAAV2 vectors have been tested in preclinical studies for a variety of diseases such as haemophilia, alphal antitrypsin deficiency, cystic fibrosis, Duchenne muscular dystrophy, rheumatoid arthritis, age-related macular degeneration (Buch et al. 2008) and others. The studies so far have shown that AAV-based vectors, particularly the AAV2 serotype, are safe and efficient tools for gene transfer (further information on AAV vectors was given by Professor Michael Linden during this meeting and is also published in this special edition of Journal of Cell biology and Toxicology).

\section{Adenoviral vectors}

Adenoviruses (Ads) have been isolated from a large number of species and tissue types, and in humans, they cause mild respiratory illnesses and gastroenteritis. Wild-type adenoviruses have a double-stranded, linear DNA genome of approximately $36 \mathrm{~kb}$ in length. Extensive splicing of the genome results in the 
production of over 50 viral proteins, 11 of which are structural virion proteins that produce the characteristic non-enveloped icosahedral protein capsid (Stewart et al. 1993). The capsid consists of three main proteins: hexon, penton base and knobbed fibre proteins (which extend from the penton base). The fibre proteins differ in length depending on the serotype. There are over 100 adenoviral serotypes identified that can infect and replicate in a wide range of organs (Verma and Weitzman 2005). This includes 51 human serotypes (HAd) that are classified into six distinct subgroups (A-F) based on their hemagglutination properties, oncogenic potential, genomic organisation and DNA homology (Arnberg 2009; Sharma et al. 2009). These subgroups exhibit distinct tissue tropism and clinical manifestations (Segerman et al. 2003a; Wadell et al. 1980). The majority of gene transfer studies utilising adenoviral vectors are derived from human $\mathrm{Ad}$ serotype 5 (HAd5), although Ad vectors have been generated from other serotypes (including human Ad2, Ad7 and Ad4 as well as non-human viruses).

Infection of host cells by wild-type Ads is mediated via cell surface receptors. The efficiency of Ad binding and entry to particular cell types is directly related to the distribution of specific receptors on the cell membrane (Mentel et al. 1997; Russell 2000) and the affinity of the different Ad subgroups to its primary receptor. For the majority of Ad serotypes (HAd2, HAd5, subgroups $\mathrm{A}, \mathrm{D}, \mathrm{E}$ and $\mathrm{F}$ but not of subgroup $\mathrm{B}$, as well as serotypes from non-human species), the major cell surface receptor is the Coxsackie adenovirus receptor (CAR; Bergelson et al. 1997; Roelvink et al. 1998). The carboxy-terminal knob domain of the fibre protein (that projects from the adenovirus capsid) binds the CAR with high affinity (Nemerow 2000). Binding between a critical RGD recognition motif in the virus penton base (Stewart et al. 1997) and with the secondary cellular integrin receptors, $\alpha_{v} \beta_{3}, \alpha_{v} \beta_{5}$ (Wickham et al. 1993), $\alpha_{v} \beta_{1}$ (Li et al. 2001), $\alpha_{3} \beta_{1}$ (Salone et al. 2003) and $\alpha_{5} \beta_{1}$ (Davison et al. 2001) has also been shown to occur. Following this binding, viral internalisation proceeds via clathrin-mediated endocytosis (Wang et al. 1998).

Recent studies are now elucidating additional receptors for various HAd serotypes, especially subgroup B. One main receptor is CD46, a ubiquitously expressed type I transmembrane glycoprotein that is a known receptor for a number of other human pathogen (Cattaneo 2004). CD46 has been identified as a cellular receptor for the majority of subgroup B HAds, including HAd3, HAd7, HAd16, HAd21, HAd50 (subspecies B1), HAd11, HAd14, HAd34 and HAd35 (subspecies B2) (Fleischli et al. 2007; Segerman et al. 2003a, b; Sharma et al. 2009), although CD46 usage by HAd3 and HAd7 remains controversial (Marttila et al. 2005; Tuve et al. 2006). In addition, subgroup D HAds (e.g. HAd37 and HAd49) has also been suggested to use CD46 as an attachment receptor (Lemckert et al. 2006; Wu et al. 2004). Additional cell surface molecules that act directly as attachment or internalisation receptors or indirectly (assisting CAR accessibility to the Ad fibre) have also been identified (Arnberg 2009). These include CD80, CD86, sialic acid, proteoglycans, major histocompatibility complex class I and vascular cell adhesion molecule I. In some cases (e.g. sialic acid), these molecules act as cellular receptors for other viruses, including influenza virus, rotavirus, cornavirus and polyomavirus (Dormitzer et al. 2002; Stehle and Harrison 1997; Weis et al. 1988), whereas the interaction with CD80 and CD86 appears to be specific to certain adenoviral subgroups, e.g. subgroup B. Cells of hematopoietic origin and neoplastic are readily transduced by subgroup B due to high levels of CD80/86 expression (Knaan-Shanzer et al. 2001; Rea et al. 2001; Short et al. 2004). Such research has prompted the proposal of an alternative classification of subgroup B HAds based on their receptor usage (Tuve et al. 2006), and it is hoped that further understanding of subgroup B HAd internalisation will advance the design of novel Ad vectors for gene delivery. Such understanding also has implications for the usage of research models. For example, the low CD46 expression on rodent cells and low homology between human and rodent CD46 means that rodents do not serve as an ideal model for subgroup B HAds. However, CD46 transgenic mouse models that have CD46 expression profile similar to monkeys and humans have been produced to serve as a suitable preclinical model for CD46-binding Ad vectors (Sakurai et al. 2006; Tatsis et al. 2007).

Once inside the cell, the virus-encoded protease assists in the gradual disruption of the virus capsid by proteolysis of viral structural proteins (Greber et al. 1997). This allows the partially disrupted virus to be transported to the nuclear membrane via the participation of dynein and microtubules (Leopold et al. 2000). The viral particle, consisting of viral DNA and 
numerous other viral-encoded proteins, is then imported through the nuclear pore into the nucleus where viral-encoded proteins form a complex with the cellular nuclear matrix to facilitate initiation of the primary transcription events. The viral DNA does not under normal circumstances integrate into the host cell genome, but remains episomal within the nucleus. The Ad genome is transcribed and replicated at discrete replication centres in the nucleus of the infected cell. Ad transcription can be defined as a two-phase event, early (E) and late (L), occurring before and after DNA replication, respectively (Fig. 1). Transcription of the four early genes, E1, E2, E3 and E4, is accompanied by numerous splicing events to generate proteins required for transactivating other viral regions or for modifying the host cellular or immunological environment. Following transport into the host cell nucleus, transcription from the viral E1 gene is initiated, producing E1a and E1b proteins. E1a proteins alter cellular metabolism and activate transcription of the other E genes (Russell 2000), whereas the E1b protein prevents apoptosis of the host cell, promoting oncogenesis and transformation. Together, E1a and E1b also inhibit inflammation caused by Ad infection (Schaack et al. 2004). The E2 gene products interact with a number of cellular factors to enable replication of viral DNA and transcription of the $\mathrm{L}$ genes. In contrast, E3 gene products are non-secreted proteins that control various host immune responses by interfering with host defence mechanisms (Horwitz 2004). As a result, they are not required for viral replication in culture (Russell 2000) and are often deleted from Ad gene therapy vectors. The E4 gene products modulate viral gene expression and replication through interaction with host cell systems. They facilitate virus messenger RNA metabolism, provide functions to inhibit host protein synthesis and promote virus DNA replication (Leppard 1997). In addition, wild-type adenoviruses also transcribe a set of untranslated RNAs (the VA RNAs) that combat cellular defence mechanisms by blocking activation of the interferon response (Mathews and Shenk 1991). Following viral DNA replication, the major late promoter in the viral genome becomes fully activated (Nevins 1981), initiating transcription and splicing of the major late transcription unit (MLTU) that produces five different transcripts (L1 to L5) that supply the viral capsid proteins (Farley et al. 2004) and aid maturation of virus particles in the nucleus.

Initial studies using Ad vectors focused on the respiratory tract (the natural target tissue of this virus). Subsequent studies demonstrated that Ads can infect a great variety of post-mitotic cells, even those associated with highly differentiated tissues such as skeletal muscle, lung, brain and heart. In 1993, Ad vector systems were first demonstrated to be a viable means

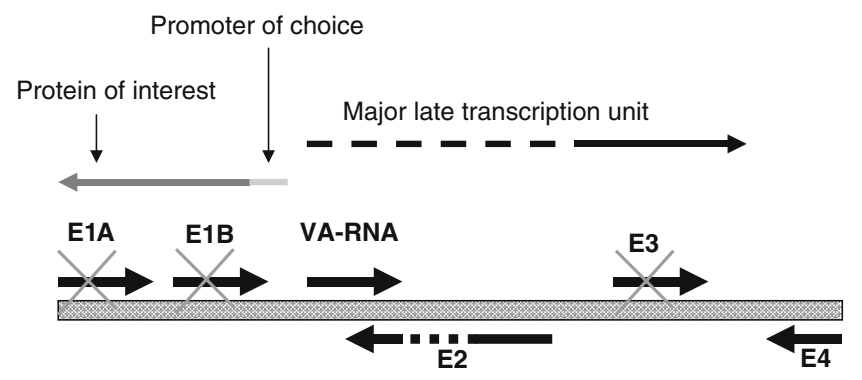

Fig. 1 Production of first-generation Ad vectors from wildtype adenovirus genome. Wild-type adenoviruses have a double-stranded, linear DNA genome of approximately $36 \mathrm{~kb}$ in length. It is divided into early $(E)$ and late $(L)$ gene transcripts. Transcription of the viral genome begins with the E1 gene, producing E1a and E1b proteins. E1a proteins alter cellular metabolism and activate transcription of the other $E$ genes, whereas the E1b protein prevents apoptosis of the host cell, promoting oncogenesis and transformation. The E2 gene products interact with a number of cellular factors to enable replication of viral DNA and transcription of the L genes. E3 gene products control various host immune responses, and the
E4 gene products modulate viral gene expression and replication. In addition, wild-type adenoviruses also transcribe a set of untranslated RNAs (the VA RNAs) that combat cellular defence mechanisms by blocking activation of the interferon response and a MLTU that produces the viral capsid proteins. The creation of first-generation replication-deficient Ad vectors involved the removal of the E1 genes. In addition, E3 genes were also removed, as they are not required for viral replication in culture. This enabled up to 8-kbp foreign DNA, encoding promoters and foreign transgenes, to be incorporated into the genome. Figure adapted from Horwood et al. Arthritis Research, 2002 
of gene transfer to the nervous system (Akli et al. 1993; Davidson et al. 1993). Wild-type Ads can only incorporate an additional $2 \mathrm{~kb}$ of foreign DNA without significant effects upon the stability of infectivity (Russell 2000). Removal of viral-encoded genes allows the incorporation of larger genetic sequences. First-generation Ad vectors were produced by removing the E1 and E3 viral cassettes, making way for approximately $8 \mathrm{~kb}$ of foreign DNA (Bett et al. 1994; Verma and Weitzman 2005). The removal of the E1 gene renders the virus extremely attenuated in its ability to replicate, and it is therefore necessary to propagate these viruses in a helper cell line that supplies the E1 gene in trans, such as the human embryonic kidney 293 (HEK293) cell line (Graham et al. 1977). The most commonly used methods to produce first-generation recombinant Ads rely on either homologous recombination in mammalian cells (Bett et al. 1994), homologous recombination in bacteria (He et al. 1998) or in vitro ligation (Mizuguchi and Kay 1998). Following homologous recombination in HEK293 cells, viral particles are screened for those expressing the inserted transgene by plaque purification. Further modifications to this method, including alterations made to the packaging cell lines, have reduced the need for this step and increased the efficiency of adenoviral production protocols (Davidson et al. 2000). Viral particles are released from HEK293 cells by sonication, separated by a $\mathrm{CsCl}$ gradient spin and purified by dialysis before storage. The high transduction efficiency of Ad vectors combined with their relative ease of preparation and purification has led to their extensive use as gene transfer vectors (Hermens and Verhaagen 1998; Verma and Weitzman 2005).

Initial in vivo studies conducted with first-generation Ad vectors revealed several limitations, including the initiation of significant systemic immune and inflammatory responses. This reduced the duration of transgene expression and limited safety and efficacy when used in vivo (Byrnes et al. 1995; Muruve 2004; Wilson 1996). Furthermore, under certain circumstances, cellular factors can transactivate viral genes that have E1Aresponsive promoters and facilitate low-level DNA replication and the production of late structural antigens. Such problems are highly apparent when firstgeneration Ad vectors are injected into peripheral organs (Spergel et al. 1992; Spergel and Chen-Kiang 1991). Transgene expression is generally undetectable after 14 days due to activation of $\mathrm{CD}^{+} \mathrm{T}$ cells that subsequently eliminate the infected cell and induce a humoral response against antigens contained in the viral capsid (Yang et al. 1994a, 1995). In addition, significant toxicity, both in vitro and in vivo, has been reported when first-generation Ad vectors are used to infect cells at higher doses (or multiplicities of infection).

To overcome such problems, extensive developments in Ad vector biology and expression cassette design have been made. Second-generation vectors were developed to address the problems of immune recognition, containing deletions in the E2a and E2b genes that encode viral DNA binding protein and DNA polymerase, respectively (Engelhardt et al. 1994; Morral et al. 1997; Yang et al. 1994b). Ad vectors deleted of E4 genes have also been investigated (Dedieu et al. 1997). The resulting recombinant viral vectors can incorporate larger transgenes (up to $10 \mathrm{kbp}$ ), are less cytotoxic and systemically immunogenic, but are unable to produce high viral titres or mediate stable transgene expression. A significant advance in Ad vector technology has been the development of helperdependent (Hd) or 'gutless' Ad vectors that are deleted of all Ad gene sequences except those required (in cis) for replication and packaging (Palmer and $\mathrm{Ng}$ 2005). A replication incompetent (helper) virus is therefore required to supply all of the necessary Ad functions in trans and is later separated from the recombinant virus (Parks et al. 1996). Consequently, the production of Hd-Ads is more complicated than earlier generations, with problems in the longevity and levels of expression (Schiedner et al. 2002) as well as helper virus contamination (Alba et al. 2005). Due to the large amount of viral DNA removed, the cloning capacity of the vector is increased and the host adaptive response is minimised. This improves the efficacy and duration of gene transfer in vivo (Muruve 2004; Parks et al. 1996), and long-term expression in immunocompetent animals, including efficient delivery to the CNS (Cregan et al. 2000; Zou et al. 2000), has been demonstrated using these vectors (Schiedner et al. 1998).

\section{Retrovirus}

Retroviruses are RNA viruses that replicate through a DNA intermediate (Kay et al. 2001). They were among the first viruses to be developed for gene therapy and have subsequently become the most 
commonly used RNA virus vectors. This large family of enveloped RNA viruses is found in all vertebrates, and they can be classified into oncoretroviruses, lentiviruses and spumaviruses (Verma and Weitzman 2005). All retroviruses consist of a lipid-enveloped virus particle (virion) that surrounds an inner core, known as the nucleocapsid. This contains two identical copies of the viral RNA genome, reverse transcriptase, integrase and protease. The nucleocapsid is surrounded by a protein shell formed by capsid proteins enclosed by a layer of matrix proteins that interact with the lipid envelope (Fig. 2).

The viral RNA forms a homodimer of linear, positive-sense, single-stranded RNA genomes containing three essential genes, gag, pol and env, that are flanked by long terminal repeat (LTR) sequences. These LTRs act in cis with neighbouring sequences during viral gene expression and packaging, retrotranscription and integration of the genome (Kay et al. 2001). The gag gene encodes for the core proteins, capsid matrix and nucleocapsid, which are generated by proteolytic cleavage of the gag precursor protein (Verma and Weitzman 2005). The pol gene encodes for the viral enzymes protease, reverse transcriptase and integrase. These are usually derived from the gag-pol precursor. Finally, the env gene encodes for the envelope glycoproteins, which mediate virus entry

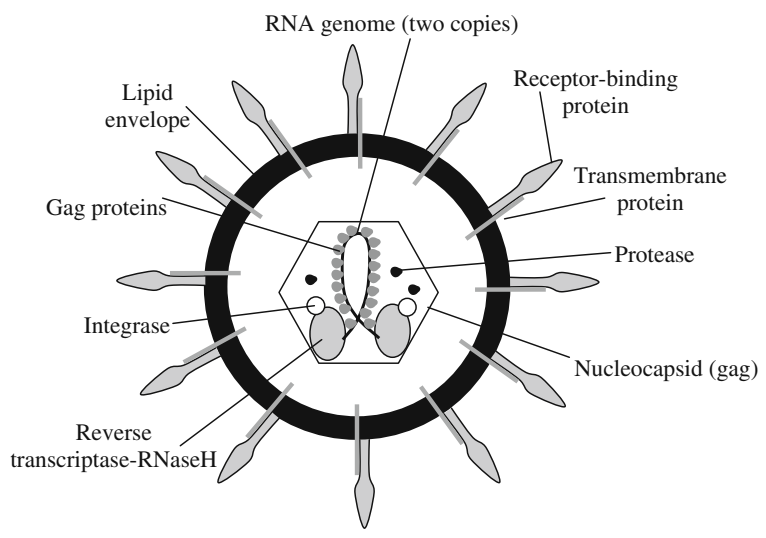

Fig. 2 Schematic of retrovirus. Retroviruses are RNA viruses that consist of a lipid envelope, depicted by the outer ring, which interacts with transmembrane matrix proteins and projecting receptor binding proteins. Host cell interactions are governed by these receptor binding proteins and can be altered by pseudotyping with other viral envelope proteins. The inner portion of the virion, known as the nucleocapsid, contains two identical copies of the viral genome and the viral reverse transcriptase, integrase and protease
(Verma and Weitzman 2005). An additional gene, the pro gene, encodes for the protease activity, responsible for gag and gag-pol cleavage and the maturation of the viral particles during or after budding.

Oncoretroviruses are simple viruses encoding only these three essential genes, whereas lentiviruses and spumaviruses are more complex and encode for additional viral proteins. However, all retroviruses infect cells by an interaction between specific host cell surface receptors (entry receptors) and co-receptors with viral envelope glycoproteins. The viral particle is then internalised through virus-cell membrane fusion, and the virus core is released into the cytoplasm (Verma and Weitzman 2005). The viral RNA genome is reversetranscribed into linear double-stranded pro-viral DNA by the viral enzyme reverse transcriptase. The proviral DNA associates with viral proteins (including nucleocapsid, reverse transcriptase and integrase) to form a pre-integration complex that is rapidly transported to the host cell nucleus. Virally encoded integrase mediates the integration of the provirus into the host cell genome, which is subsequently transcribed into RNA from the viral promoter contained in the 5' LTR. This process is initiated by host cell transcription factors, and once transcribed, the viral RNA is transported to the cytoplasm where it is translated into viral proteins. The required viral structural proteins and replication enzymes (i.e. gag-pol and gag precursors) assemble with two copies of the viral RNA to form new virion cores at the plasma membrane (Verma and Weitzman 2005).

The first retroviral vectors to be developed and used in a gene therapy trial were based on the 'simple' moloney murine leukaemia virus (MMLV, an oncovirus; Blaese et al. 1995). Since their initial use, retroviruses have been used for stable gene transfer into mammalian cells for over 20 years (Barquinero et al. 2004). They are often the method of choice as they provide lifelong expression of the introduced gene due to integration into the host cell genome. However, simple retroviruses such as MMLV require the disruption of the nuclear membrane at mitosis to grant the pre-integration complex access to the chromatin and subsequently integrate into the host cell genome (Roe et al. 1993). Consequently, simple retroviral vectors are of limited use for gene transfer to post-mitotic neurons. Nevertheless, MMLV has been used to deliver genes to the brain in an ex vivo manner. For example, MMLV-mediated transfer of the tyrosine hydroxylase gene to fibroblast 
and astrocyte cells in culture has been demonstrated, and subsequent transplantation of these cells results in partial behavioural recovery in the 6-OHDA model of Parkinson's disease (Wolff et al. 1989).

\section{Lentivirus}

Lentiviruses are a subgroup of the retrovirus family. Their genomes are slightly more complicated, containing accessory genes that regulate viral gene expression, control the assembly of infectious particles, modulate viral replication in infected cells and contribute to the persistence of infection (Kay et al. 2001). For example, human immunodefiency virus-1 (HIV-1), a commonly used lentiviral vector, encodes six additional proteins (tat, rev, vif, vpr, nef and vpu; Frankel and Young 1998; Verma and Weitzman 2005). These proteins are involved with budding, maturation and integration steps of the viral life cycle, enhancing the rate of transcription and nuclear export of the viral RNA as well as assisting in the assembly of the virion (Blesch 2004). In addition, lentiviral vectors do not require the breakdown of the nuclear membrane in order to integrate (Lewis and Emerman 1994). The lentivirusencoded gag matrix protein, integrase enzyme (Gallay et al. 1997) and $v p r$ protein (Heinzinger et al. 1994) interact with the nuclear import machinery of the target cell and facilitate active transport of the pre-integration complex through the nucleopore. This enables transfection of non-dividing cells, and as a result, such 'complex retroviruses' have shown promise as gene transfer vectors, especially for post-mitotic cells such as neurons (Blomer et al. 1996; Naldini et al. 1996; Vigna and Naldini 2000).

Lentiviral vectors were developed by the removal of all viral genes, except those required (in cis) in order to complete a single round of replication. All other components are supplied in trans from either transient transfection or stable cell lines. HEK293T cells, a derivative of HEK293 cells that contain the SV40 large T-antigen, are often used for lentiviral production. In addition, the viral rev protein is provided in trans, as are gag and pol, achieved by co-transfection of helper cell lines (Pacchia et al. 2001; Fig. 3). Following co-transfection of helper plasmids with the shuttle plasmid, expressing the foreign transgene of choice, the viral vector particles are produced and released into the media by the budding process. The resulting lentiviral vectors are then purified and concentrated by ultracentrifugation. Further advances in lentiviral vector design involving the deletion of further non-essential pathogenic genes reduced the HIV-derived packaging component of second-generation vectors to the gag, pol, tat and rev
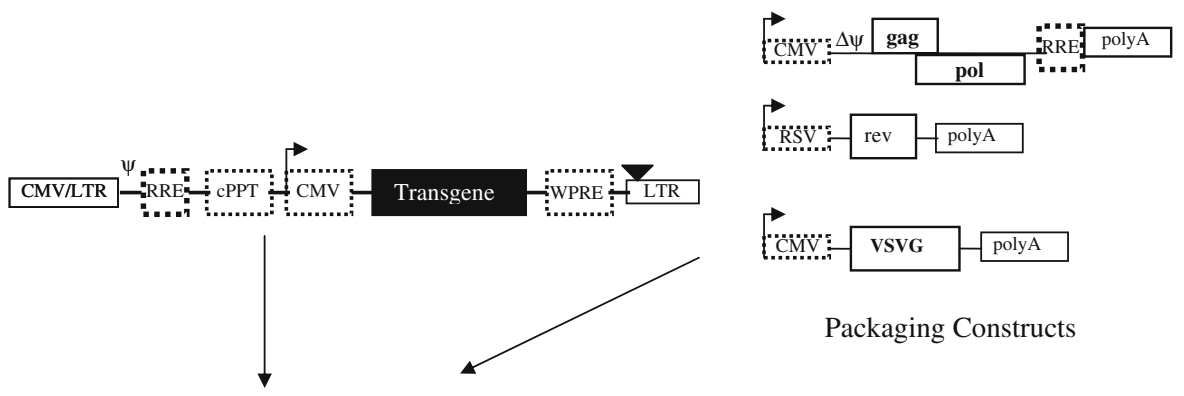

Cotransfection into HEK293T cells

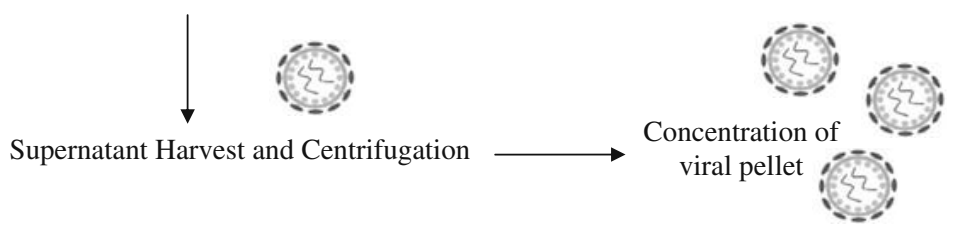

Fig. 3 Production of lentiviral vectors. Lentiviral vectors are produced by co-transfection of packaging constructs containing viral elements needed for one round of replication, together with the shuttle vector containing the transgene into a packaging cell line, e.g. HEK293T cells. The newly formed viral particles are released into the supernatant by the budding process and can be collected (harvested) and concentrated by centrifugation. Addition of viral components such as the cPPT, RRE and WPRE can enhance the production and subsequent transgene expression 
genes of HIV-1 (Delenda 2004; Kim et al. 1998; Zufferey et al. 1997). Third-generation lentiviral vectors see the replacement of the tat gene with powerful constitutive promoters, such as the immediate early cytomegaly virus (CMV) promoter (Dull et al. 1998; Kim et al. 1998), increasing the bio-safety of these vectors. These minimal vector systems have the essential viral components segregated onto three or four separate plasmids with minimal sequence overlap. An additional safety concern of using lentiviralbased vector systems is the possibility of insertional activation of an oncogene following random integration of the vector provirus into the host genome. This problem has been addressed by the development of self-inactivating lentiviral vectors (Miyoshi et al. 1998; Xu et al. 2001). These vectors contain deletions in the U3 region of the $3^{\prime}$ LTR, which is transferred to the promoter in the $5^{\prime}$ LTR after reverse transcription and eliminates transcriptional activation of surrounding host genes (Logan et al. 2004). Thus, recombinant lentiviral vectors are now constructed using only three HIV-1 genes: gag, pol and rev. The cloning vectors, into which genes of interest are placed, are devoid of all viral sequences apart from essential cis-acting sequences, including the LTRs and the packaging signal. The rev responsive element (RRE) is also included to ensure efficient nuclear export of the fulllength viral RNA genome.

Despite advances addressing safety concerns of using lentiviral vectors, there are still problems regarding limited transgene capacity, difficulties in constructing stable producer cell lines due to viral gene toxicity, and thus the inability to produce hightitre stocks. The reintroduction of other viral sequences, such as the central polypurine tract (cPPT) and the central termination sequence from the HIV pol gene, improves gene expression (Barry et al. 2001; De Rijck et al. 2005; Logan et al. 2004). These sequences (regardless of their position within the viral vector; De Rijck et al. 2005) improve translocation of the pre-integration complex, resulting in increased nuclear transduction efficiency and production of higher viral titres. Incorporation of a posttranscriptional regulatory element into lentiviral vectors increases nuclear RNA export, stabilises the viral vector mRNA and hence increases translation and transgene expression (Zufferey et al. 1999).

The majority of lentiviral vector development has focused on primate lentivirus-based systems, such as
HIV-1. However, other gene transfer systems based on non-primate lentiviruses, such as the feline immunodeficiency virus (FIV; Curran et al. 2000; Poeschla et al. 1998) and the equine infectious anaemia virus (EIAV; Olsen 1998), have also been developed. Since their initial development, these systems have been optimised, producing minimal cassettes that include additional regulatory elements (similar to those used in HIV-1-based systems; Johnston et al. 1999; Saenz and Poeschla 2004) and have been pseudotyped with alternative envelope glycoproteins (Mazarakis et al. 2001; Sinn et al. 2005; Song et al. 2003; Wong et al. 2004). These nonprimate-based systems can successfully transduce dividing and non-dividing cells (Mitrophanous et al. 1999) and can mediate neuronal gene expression in vivo (Azzouz et al. 2004; Azzouz and Mazarakis 2004; Wong et al. 2005). Such systems are thought to be inherently safer, as humans are not the host of the wild-type virus, although early EIAV systems were limited by the instability of vector-derived RNA transcripts and silencing of the EIAV over time (O'Rourke et al. 2002). Development of these systems has eliminated such problems, and many studies show that EIAV vectors can now transduce human cells with similar efficiency to HIV-1.

Gene therapy trials have highlighted concerns regarding the propensity for lentiviral vectors (including HIV-1) to integrate within transcriptionally active regions known as euchromatin. Genomic integration of lentiviral vector genome facilitates long-term expression as the viral sequence is replicated during mitosis. This desirable trait can also be a problem, especially when the insertion site is in close proximity to a proto-oncogene (Somia and Verma 2000). In recent clinical gene therapy trials for X-linked severe combined immunodeficiency, five children developed leukaemia as a direct consequence of insertional mutagenesis (Staal et al. 2008). In two cases, retrovirus integration was in proximity to the LMO2 proto-oncogene promoter, leading to aberrant transcription and expression of LMO2 (Hacein-BeyAbina et al. 2003). The development of nonintegrating lentiviral vectors, where the viral genome remains episomal, may address such problems. Although such vectors offer a limited expression window in mitotic cells, good expression is produced in post-mitotic cells, such as neurons (Yanez-Munoz et al. 2006). Initial studies using non-integrating 
lentiviral vectors have indicated that they are able to efficiently replicate and express the transgene (Fig. 4).

\section{Targeted gene transfer and regulatable expression}

Various modifications have been employed in an effort to improve the targeting of viral vectors to specific cells and regulate transgene expression. Improved targeting has primarily been achieved by pseudotyping, altering the uptake of viral particles into specific cells by altering viral surface proteins/ envelope proteins to that of another viral subtype. Such retargeting of Ad vectors away from its primary receptor (CAR) to a tissue- or cell-specific receptors has been achieved by utilising different serotypes of adenovirus (Havenga et al. 2002). In addition, some rare HAd serotypes (Stone and Lieber 2006) and nonhuman Ads (Bangari and Mittal 2006) are now also being developed and investigated as alternate vectors for gene delivery. In addition to pseudotyping, targeting can be altered by specifically altering the viral capsid proteins by mutations, genetically modifying the fibre and knob fibre proteins (Bakker et al. 2001; Nicklin et al. 2001). Such modifications can (1) increase the tropism of Ad vectors, making cells normally refractory to transduction (due to low CAR expression) accessible targets; (2) restrict transduction to the organ of interest enabling a lower dose to be used and (3) limit transgene transcription to certain cell types. Various studies have now demonstrated that the incorporation of additional RGD motifs on Ad fibre knobs can enhance the Ad transduction to a wide variety of cells (including endothelial cells, smooth muscle, fibroblasts, numerous tumour cell types and dendritic cells) that express low levels of CAR but high levels of integrins (Okada et al. 2001; Staba et al. 2000; Wickham et al. 1997). In addition, manipulation of such motifs may minimise the innate immune response by limiting vector interaction with the reticuloendothelial system, potentially avoiding the effects of an anti-adenoviral neutralising antibody response, and reduce the enhanced tropism for hepatocytes often displayed by Ad vectors. The latter is due to binding of coagulation factor IX, complement component C4-binding protein and vitamin Kdependent blood coagulation factors (FVII, FIX, FX and protein $\mathrm{C}$ ) to the Ad fibre knob or hexon protein which then acts as a link for virus uptake by hepatocytes through heparan sulfate proteoglycan or LDL receptor-related protein (Arnberg 2009; Parker et al. 2006; Waddington et al. 2008). Such retargeting will ultimately reduce systemic toxicity, especially following peripheral administration of Ad vectors.

The targeting of lentiviral vectors has been modified in a similar way, utilising the envelope proteins of various retroviruses to enhance targeting to a particular cell type (Bouard et al. 2009 for review). Early versions of recombinant HIV vectors were of limited use due to their strict host cell tropism (CD4 ${ }^{+}$ targets; Poznansky et al. 1991; Shimada et al. 1991). Pseudotyping with the vesicular stomatitis virus $G$
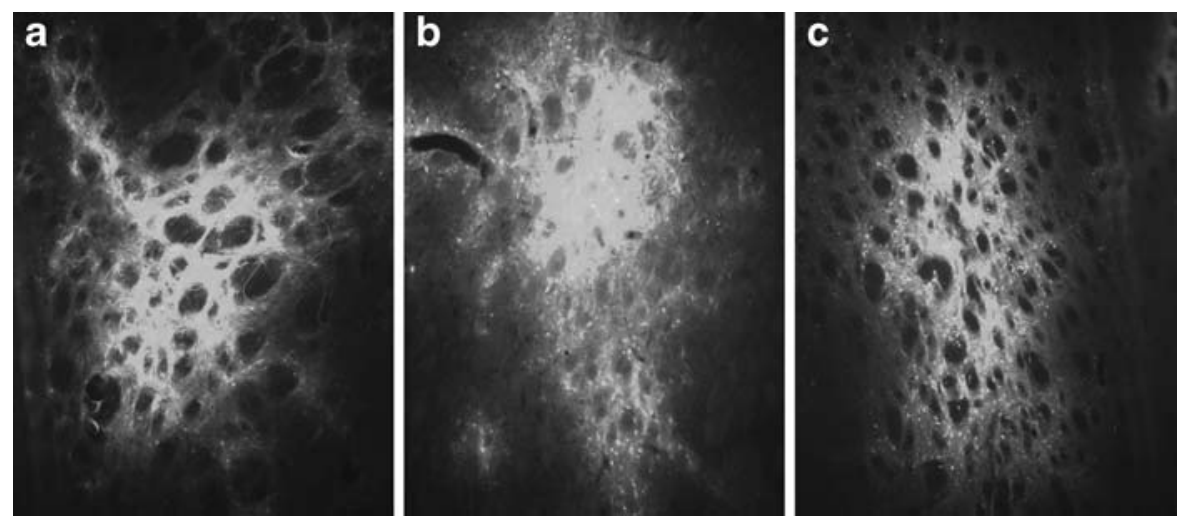

Fig. 4 Non-integrating lentiviral vectors. Modification of lentiviral plasmids to contain an integrase negative helper plasmid have enabled the development of non-integrating lentiviral vectors. The viral genome does not integrate into the host genome but remains episomal. Transduction with EGFPexpressing virus demonstrates the efficiency of these vectors: a Integrating lenti-CMV-EGFP, b non-integrating CMV-EGFP and $\mathbf{c}$ non-integrating synapsin-EGFP 
(VSV-G) envelope protein substantially reduces the potential to form wild-type virus (Kafri et al. 1999; Naldini et al. 1996), increases viral stability and increases the host cell tropism, enabling transfection of both dividing and non-dividing cells in vitro (Kafri et al. 1999; Naldini et al. 1996; Reiser et al. 1996) and neurons following direct injection in the brain (Naldini et al. 1996). VSV-G psuedotyping is now widely used, and such vectors recently gained FDA clearance and have entered clinical application (Lu et al. 2004; Manilla et al. 2005). However, VSV-G can be inactivated by serum complement (DePolo et al. 2000) and has been shown to be toxic following longterm infection. Recent studies have therefore investigated pseudotyping with alternative glycoproteins (GPs) derived from other viruses, each with specific advantages and disadvantages (Cronin et al. 2005). Examples include pseudotyping with rabies, Ebola Zaire (EboZ), lymphocytic choriomeningitis virus (LCMV), alpha viruses, Sindbis virus and Hantavirus glycoproteins. Both HIV-1 lentiviral and EIAV vectors have been successfully pseudotyped with various rabies virus glycoproteins (Conzelmann et al. 1990; Mebatsion et al. 1995; Mitrophanous et al. 1999; Mochizuki et al. 1998). These glycoproteins enable retrograde transport of transgene expression along nerve tracts and into distal brain areas (Wong et al. 2004). MLV-based retroviral vectors pseudotyped with the LCMV GP have been shown to efficiently transduce fibroblasts, epithelial cells, hematopoietic cells, as well as hepatoma, neuroblastoma and glioma cell lines (Miletic et al. 1999). FIV LCMV-WE pseudotypes are potentially useful for targeting neural stem/progenitor cells in vivo. Several reports describing successful pseudotyping of lentiviral vectors with GP from alpha viruses (river virus (RRV), Semliki forest virus and Sindbis virus) have also been described. RRV-pseudotyped FIV vectors (RRV/FIV) predominantly transduced the liver of recipient mice with a 20 -fold higher transduction efficiency than that achieved with a VSV-G pseudotype that caused less cytotoxicity. Non-hepatocytes (mainly Kupffer cells) were also transduced, and following injection into the brain, RRV/FIV preferentially transduced neuroglial cells (astrocytes and oligodendrocytes; Kang et al. 2002). Intravenous injection of oncoretroviruses and lentiviruses pseudotyped with a modified chimeric Sindbis virus shows high targeting specificity and low nonspecific infectivity in liver and spleen (Morizono et al. 2001). Successful pseudotyping of HIV-1 vectors using Marburg virus and EboZ virus-derived virion GPs has also been described. Such vectors were more efficient in transducing myocytes, and EboZ pseudotyped vectors injected into muscle in utero were found to transduce muscle satellite or stem cells and lead to transgene expression in newly regenerated muscle after injury (MacKenzie et al. 2005). Direct brain injection of EboZ/HIV pseudotypes in adult mice failed to transduce cells in the brain (Watson et al. 2002). This may be due to the lack of the proper receptor in the CNS. However, EboZ pseudotypes were able to efficiently transduce the apical surface of airway epithelia after apical application (Kobinger et al. 2001), and therefore, these vectors are now being employed for cystic fibrosis studies (Sanders 2004). Modified lentiviral vector pseudotyped with a strain of Hantavirus (HTNV) has also been used to improve the transduction efficiency into vascular smooth muscle and endothelial cells in vitro and in vivo (Qian et al. 2006).

The physical targeting of viral vectors can also be modified by coating the virus surface with polymers such as polyethylene glycol, poly-[ $N$-(2-hydroxypropyl) methacrylamide] or biodegradable alginate microparticles (Croyle et al. 2000; Kreppel and Kochanek 2008; Sailaja et al. 2002). Such modifications ablate the native tropism of the vector and shield it from the host immune response whilst allowing selective targeting by the attachment of a variety of targeting ligands (peptides, proteins or antibodies) to these polymers (Kreppel and Kochanek 2008; Morrison et al. 2008). As mentioned previously, physical targeting of Ad vectors has been altered by the use of bispecific adaptor molecules (including bispecific antibodies or fusion proteins; Dmitriev et al. 2000; Parrott et al. 2003; Reynolds et al. 2001). In this strategy, however, the two-component nature of bispecific molecules adds complications in manufacturing and in maintaining batch-to-batch homogeneity. Furthermore, these modifications would not be inherited by progeny virions, and therefore, genetic modification of the capsid proteins is a more favoured option at this time.

In addition to these viral particle targeting methods, tissue-specific promoters or tissue-specific regulatory elements (Nettelbeck 2008) have been used to limit transgene expression to the tissue of interest. Some tissue-specific promoters investigated are glial fibrillary acidic protein (GFAP), synapsin, muscle creatine 
kinase (MCK), phosphoglycerate kinase and neuronalspecific enolase (NSE). Muscle-specific expression has been achieved using the MCK promoter in both adenoviral and lentiviral systems (Ferrari et al. 1995; Larochelle et al. 1997). AAV9 vectors containing the Desmin promoter have also been used to produce gene expression in cardiac and skeletal muscle following systemic vector administration (Pacak et al. 2008). Bone-specific expression has been achieved using the murine leukaemia virus long terminal repeat promoter (RhMLV; Phillips et al. 2007) or the human osteogenic promoter osteocalcin (Kofron and Laurencin 2006). One major field of research has focused on brainspecific expression. Several promoters have been tested for targeting to the CNS using AAV vectors (Terzi and Zachariou 2008). These include CMV, NSE, plateletderived growth factor-b and CMV-chicken $\beta$-actin (Shevtsova et al. 2005). Similar studies have been performed using Ad and lentiviral vectors (Jakobsson et al. 2003; Virta et al. 2006). Cell specificity achieved by particular promoters can vary between different CNS regions (Peel et al. 1997). GFAP promoter has been shown to drive exclusive transduction in spinal cord, hippocampal and striatal neurons. The synapsin promoter has also been utilised in Ad, lentiviral and AAV vectors systems to drive neuron-specific expression (Glover et al. 2003; Nathanson et al. 2009; Peel et al. 1997; Sims et al. 2008; Fig. 5).

Viral vector utility has also been improved by the incorporation of regulatable expression systems, such as tetracycline (Harding et al. 1998) and RU486 (Burcin et al. 1999) inducible systems. Tetracycline inducible systems have produced highly regulatable
Ad vectors (Harding et al. 1997, 1998), allowing transgene expression to be switched on and off in vivo by the simple addition of doxycycline (a tetracycline analog) in drinking water. Such systems can enable the production of vectors that contain toxic inserts, acting specifically and at high levels in the "On" state, and show dose-responsive expression allowing varied levels of gene expression. Subsequent studies have combined this system with cell-specific promoters to drive neuron-specific and glial-specific regulatable transgene expression (Glover et al. 2002, 2003; Lee et al. 2005; Ralph et al. 2000). The wellcharacterised tetracycline-based regulatable systems have also been utilised in lentiviral vector design (Kafri et al. 2000) and AAV-based studies (Stieger et al. 2009). Such lentiviral systems have already been used to mediate regulated delivery of genes thought to alleviate symptoms of Parkinson's disease (Georgievska et al. 2004; Vogel et al. 2004).

A range of viral vectors are therefore available to aid research, each suited for different purposes/applications due to their individual characteristics. Ad vectors have been greatly utilised for in vitro studies, transferring genetic material into many cell lines and cultured cell systems. Within our laboratory, they have been utilised to generate in vitro models of polyglutamine diseases in both a mouse neuroblastoma cell line and primary neurons (Fig. 6). Viral-mediated gene transfer enables the production of dose-dependant models where the level of disease protein expression (and therefore the severity of the disease state) can be modified by viral dose as well as the length of the CAG repeat tract within the expressed transgene. Expression within primary

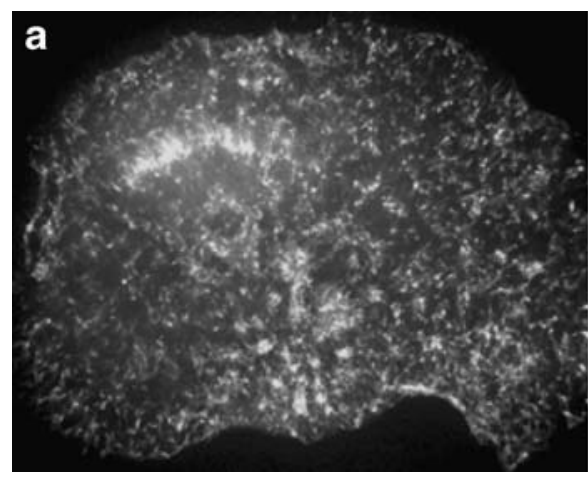

Fig. 5 Neuron-specific expression using the synapsin promoter. Modification of adenoviral vectors using tissue-specific promoters to produce specific expression in embryonic rat organo-

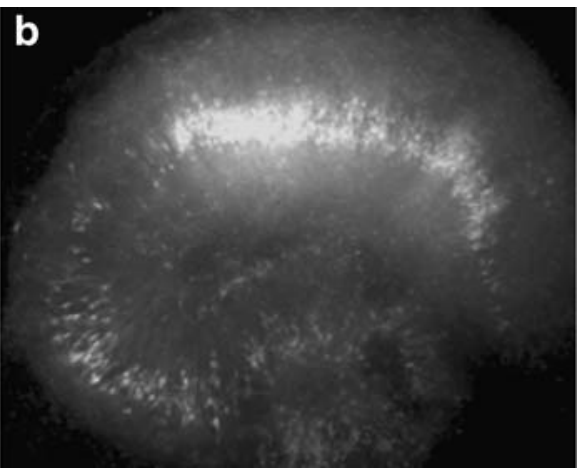

typic brain cultures: a Ad-CMV-EGFP results in ubiquitous expression. b Ad-Syn-EGFP vectors, containing the human synapsin promoter, produces neuron-specific expression 
neurons has been achieved using the neuron-specific synapsin promoter to drive neuronal-enriched expression of polyQ proteins (Howarth et al. 2009). Lentiviral vectors have subsequently been used to create an in vivo model of polyQ disease in rat striatum (Howarth et al. 2007). The initial enthusiasm behind viral vector technologies is therefore still founded, especially in the laboratory setting where they provide a useful tool to enable the genetic manipulation of cells in vitro without the need for traditional transfection methods. The advent of lentiviral vectors has enabled the creation of 'stable' cell lines as well as an in vivo expression system with true longevity. In terms of gene therapy, many lessons have been learnt from clinical trials where problems of immune response and insertional mutagenesis have been highlighted (Staal et al. 2008). Such difficulties are slowly being addressed, and further developments involving improved targeting, production, transgene expression and limitations of longevity are frequently occurring in each system. In addition, new technologies, including that of cell-based delivery of Ad vectors (Power and Bell 2007), are also driving the field forward, and certain vector systems are proving instrumental in clinical breakthroughs. Of particular note are the advances in glioma therapy utilising HSV vectors (Markert et al. 2006; Todo 2008) and the development in AAV vectors (Buning et al. 2008; Monahan and Samulski 2000), including clinical trials for retinal therapy (Buch et al. 2008).
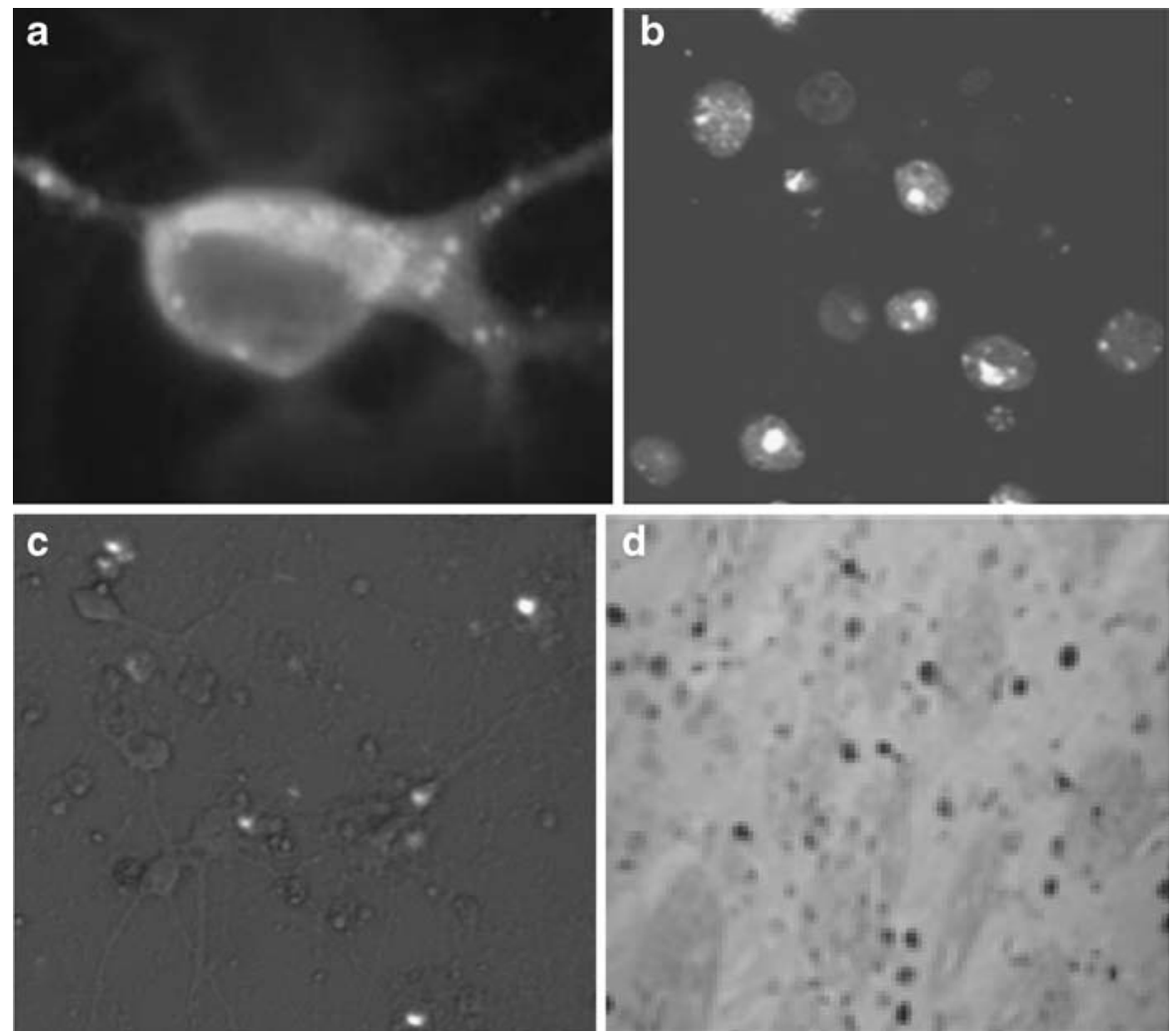

Fig. 6 Utilising viral vectors to create models of polyglutamine disease. a SBMA model in mouse neuroblastoma cell line. Transduction of mouse neuroblastoma cells, N2a's, with adenoviral vectors expressing the androgen receptor construct that contains an expanded polyglutamine (CAG) repeat tract, leads to the development of protein aggregates within the cytoplasm upon testosterone addition. b Adenoviral vectors are used to create a model of polyglutamine in dissociated primary cortical neurons. These viruses express polyQ construct tagged with EGFP, driven by the synapsin promoter to enhance neuron-specific expression. c A similar model is also produced following the transduction of dissociated primary cortical neurons with adenoviral vectors expressing huntingtin with 103 PolyQ repeats fused to EGFP. d Lentiviral vectors expressing the polyQ-EGFP constructs are injected into rat striatum to create an in vivo model of polyglutamine disease 
Acknowledgements This review is based upon the talk given at ETCS-UK 1 day Symposium on Genetic Manipulation of Cells. I would like to thank them for their invitation. I also thank Drs. Stephen Kelly and Liang Fong Wong for the critical reading of this manuscript. All work presented from our laboratory has been funded by the Wellcome Trust and BBSRC.

Open Access This article is distributed under the terms of the Creative Commons Attribution Noncommercial License which permits any noncommercial use, distribution, and reproduction in any medium, provided the original author(s) and source are credited.

\section{References}

Afione SA, Conrad CK, Kearns WG, Chunduru S, Adams R, Reynolds TC, et al. In vivo model of adeno-associated virus vector persistence and rescue. J Virol. 1996;70:3235-41.

Akli S, Caillaud C, Vigne E, Stratford-Perricaudet LD, Poenaru $\mathrm{L}$, Perricaudet $\mathrm{M}$, et al. Transfer of a foreign gene into the brain using adenovirus vectors. Nat Genet. 1993;3:224-8.

Alba R, Bosch A, Chillon M. Gutless adenovirus: last-generation adenovirus for gene therapy. Gene Ther. 2005;12(Suppl 1): S18-27.

Arnberg N. Adenovirus receptors: implications for tropism, treatment and targeting. Rev Med Virol. 2009;19:165-78.

Arnold GS, Sasser AK, Stachler MD, Bartlett JS. Metabolic biotinylation provides a unique platform for the purification and targeting of multiple AAV vector serotypes. Molec Ther. 2006;14:97-106.

Azzouz M, Mazarakis N. Non-primate EIAV-based lentiviral vectors as gene delivery system for motor neuron diseases. Curr Gene Ther. 2004;4:277-86.

Azzouz M, Le T, Ralph GS, Walmsley L, Monani UR, Lee DC, et al. Lentivector-mediated SMN replacement in a mouse model of spinal muscular atrophy. $\mathrm{J}$ Clin Invest. 2004;114:1726-31.

Bakker AC, Van de Loo FA, Joosten LA, Bennink MB, Arntz OJ, Dmitriev IP, et al. A tropism-modified adenoviral vector increased the effectiveness of gene therapy for arthritis. Gene Ther. 2001;8:1785-93.

Bangari DS, Mittal SK. Development of nonhuman adenoviruses as vaccine vectors. Vaccine. 2006;24:849-62.

Barquinero J, Eixarch H, Perez-Melgosa M. Retroviral vectors: new applications for an old tool. Gene Ther. 2004;11 (Suppl 1):S3-9.

Barry SC, Harder B, Brzezinski M, Flint LY, Seppen J, Osborne WR. Lentivirus vectors encoding both central polypurine tract and posttranscriptional regulatory element provide enhanced transduction and transgene expression. Hum Gene Ther. 2001;12:1103-8.

Bartlett JS, Kleinschmidt J, Boucher RC, Samulski RJ. Targeted adeno-associated virus vector transduction of nonpermissive cells mediated by a bispecific F(ab'gamma) 2 antibody. Nat Biotechnol. 1999;17:181-6.

Bergelson JM, Cunningham JA, Droguett G, Kurt-Jones EA, Krithivas A, Hong JS, et al. Isolation of a common receptor for Coxsackie $\mathrm{B}$ viruses and adenoviruses 2 and 5. Science. 1997;275:1320-3.
Bett AJ, Haddara W, Prevec L, Graham FL. An efficient and flexible system for construction of adenovirus vectors with insertions or deletions in early regions 1 and 3. Proc Natl Acad Sci USA. 1994;91:8802-6.

Blaese RM, Culver KW, Miller AD, Carter CS, Fleisher T, Clerici $\mathrm{M}$, et al. T lymphocyte-directed gene therapy for ADA- SCID: initial trial results after 4 years. Science. 1995;270:475-80.

Blesch A. Lentiviral and MLV based retroviral vectors for ex vivo and in vivo gene transfer. Methods. 2004;33:164-72.

Blomer U, Naldini L, Verma IM, Trono D, Gage FH. Applications of gene therapy to the CNS. Hum Mol Genet. 1996;5(spec no.):1397-404.

Bouard D, Alazard-Dany D, Cosset FL. Viral vectors: from virology to transgene expression. Br J Pharmacol. 2009;157:153-65.

Buch PK, Bainbridge JW, Ali RR. AAV-mediated gene therapy for retinal disorders: from mouse to man. Gene Ther. 2008;15:849-57.

Buning H, Perabo L, Coutelle O, Quadt-Humme S, Hallek M. Recent developments in adeno-associated virus vector technology. J Gene Med. 2008;10:717-33.

Burcin MM, Schiedner G, Kochanek S, Tsai SY, O'Malley BW. Adenovirus-mediated regulable target gene expression in vivo. Proc Natl Acad Sci USA. 1999;96:355-60.

Byrnes AP, Rusby JE, Wood MJ, Charlton HM. Adenovirus gene transfer causes inflammation in the brain. Neuroscience. 1995;66:1015-24.

Cattaneo R. Four viruses, two bacteria, and one receptor: membrane cofactor protein (CD46) as pathogens' magnet. J Virol. 2004;78:4385-8.

Cearley CN, Vandenberghe LH, Parente MK, Carnish ER, Wilson JM, Wolfe JH. Expanded repertoire of AAV vector serotypes mediate unique patterns of transduction in mouse brain. Molec Ther. 2008;16:1710-8.

Conzelmann KK, Cox JH, Schneider LG, Thiel HJ. Molecular cloning and complete nucleotide sequence of the attenuated rabies virus SAD B19. Virology. 1990;175:485-99.

Coura RS, Nardi NB. The state of the art of adeno-associated virus-based vectors in gene therapy. Virol J. 2007;4:99.

Cregan SP, MacLaurin J, Gendron TF, Callaghan SM, Park DS, Parks RJ, et al. Helper-dependent adenovirus vectors: their use as a gene delivery system to neurons. Gene Ther. 2000;7:1200-9.

Cronin J, Zhang XY, Reiser J. Altering the tropism of lentiviral vectors through pseudotyping. Curr Gene Ther. 2005;5:387-98.

Croyle MA, Yu QC, Wilson JM. Development of a rapid method for the PEGylation of adenoviruses with enhanced transduction and improved stability under harsh storage conditions. Hum Gene Ther. 2000;11:1713-22.

Cuchet D, Potel C, Thomas J, Epstein AL. HSV-1 amplicon vectors: a promising and versatile tool for gene delivery. Expert. Opin. Biol. Ther. 2007;7:975-95.

Curran MA, Kaiser SM, Achacoso PL, Nolan GP. Efficient transduction of nondividing cells by optimized feline immunodeficiency virus vectors. Molec Ther. 2000;1:31-8.

Davidson BL, Allen ED, Kozarsky KF, Wilson JM, Roessler BJ. A model system for in vivo gene transfer into the central nervous system using an adenoviral vector. Nat Genet. 1993;3:219-23.

Davidson BL, Stein CS, Heth JA, Martins I, Kotin RM, Derksen TA, et al. Recombinant adeno-associated virus 
type 2, 4, and 5 vectors: transduction of variant cell types and regions in the mammalian central nervous system. Proc Natl Acad Sci USA. 2000;97:3428-32.

Davison E, Kirby I, Whitehouse J, Hart I, Marshall JF, Santis G. Adenovirus type 5 uptake by lung adenocarcinoma cells in culture correlates with Ad5 fibre binding is mediated by alpha(v)beta1 integrin and can be modulated by changes in beta1 integrin function. J Gene Med. 2001;3:550-9.

Daya S, Berns KI. Gene therapy using adeno-associated virus vectors. Clin Microbiol Rev. 2008;21:583-93.

De Rijck J, Van MB, Debyser Z. Positional effects of the central DNA flap in HIV-1-derived lentiviral vectors. Biochem Biophys Res Commun. 2005;328:987-94.

Dedieu JF, Vigne E, Torrent C, Jullien C, Mahfouz I, Caillaud JM, et al. Long-term gene delivery into the livers of immunocompetent mice with E1/E4-defective adenoviruses. J Virol. 1997;71:4626-37.

Delenda C. Lentiviral vectors: optimization of packaging, transduction and gene expression. J Gene Med. 2004;6 (Suppl 1):S125-38.

DePolo NJ, Reed JD, Sheridan PL, Townsend K, Sauter SL, Jolly DJ, et al. VSV-G pseudotyped lentiviral vector particles produced in human cells are inactivated by human serum. Molec Ther. 2000;2:218-22.

Dmitriev I, Kashentseva E, Rogers BE, Krasnykh V, Curiel DT. Ectodomain of coxsackievirus and adenovirus receptor genetically fused to epidermal growth factor mediates adenovirus targeting to epidermal growth factor receptorpositive cells. J Virol. 2000;74:6875-84.

Dormitzer PR, Sun ZY, Blixt O, Paulson JC, Wagner G, Harrison SC. Specificity and affinity of sialic acid binding by the rhesus rotavirus VP8* core. J Virol. 2002;76:10512-7.

Dull T, Zufferey R, Kelly M, Mandel RJ, Nguyen M, Trono D, et al. A third-generation lentivirus vector with a conditional packaging system. J Virol. 1998;72:8463-71.

Engelhardt JF, Ye X, Doranz B, Wilson JM. Ablation of E2A in recombinant adenoviruses improves transgene persistence and decreases inflammatory response in mouse liver. Proc Natl Acad Sci USA. 1994;91:6196-200.

Epstein AL. HSV-1-based amplicon vectors: design and applications. Gene Ther. 2005;12(Suppl 1):S154-8.

Farley DC, Brown JL, Leppard KN. Activation of the early-late switch in adenovirus type 5 major late transcription unit expression by L4 gene products. J Virol. 2004;78:1782-91.

Ferrari G, Salvatori G, Rossi C, Cossu G, Mavilio F. A retroviral vector containing a muscle-specific enhancer drives gene expression only in differentiated muscle fibers. Hum Gene Ther. 1995;6:733-42.

Fleischli C, Sirena D, Lesage G, Havenga MJ, Cattaneo R, Greber UF, et al. Species B adenovirus serotypes 3, 7, 11 and 35 share similar binding sites on the membrane cofactor protein CD46 receptor. J Gen Virol. 2007;88:2925-34.

Frankel AD, Young JA. HIV-1: fifteen proteins and an RNA. Annu Rev Biochem. 1998;67:1-25.

Fu H, Muenzer J, Samulski RJ, Breese G, Sifford J, Zeng X, et al. Self-complementary adeno-associated virus serotype 2 vector: global distribution and broad dispersion of AAVmediated transgene expression in mouse brain. Molec Ther. 2003;8:911-7.

Gallay P, Hope T, Chin D, Trono D. HIV-1 infection of nondividing cells through the recognition of integrase by the importin/karyopherin pathway. Proc Natl Acad Sci USA. 1997;94:9825-30.

Gao GP, Alvira MR, Wang L, Calcedo R, Johnston J, Wilson JM. Novel adeno-associated viruses from rhesus monkeys as vectors for human gene therapy. Proc Natl Acad Sci USA. 2002;99:11854-9.

Georgievska B, Jakobsson J, Persson E, Ericson C, Kirik D, Lundberg C. Regulated delivery of glial cell linederived neurotrophic factor into rat striatum, using a tetracycline-dependent lentiviral vector 1 . Hum Gene Ther. 2004;15:934-44.

Glorioso JC, Fink DJ. Herpes vector-mediated gene transfer in the treatment of chronic pain. Molec Ther. 2009;17: $13-8$.

Glover CP, Bienemann AS, Heywood DJ, Cosgrave AS, Uney JB. Adenoviral-mediated, high-level, cell-specific transgene expression: a SYN1-WPRE cassette mediates increased transgene expression with no loss of neuron specificity. Molec Ther. 2002;5:509-16.

Glover CP, Bienemann AS, Hopton M, Harding TC, Kew JN, Uney JB. Long-term transgene expression can be mediated in the brain by adenoviral vectors when powerful neuronspecific promoters are used. J Gene Med. 2003;5:554-9.

Graham FL, Smiley J, Russell WC, Nairn R. Characteristics of a human cell line transformed by DNA from human adenovirus type 5. J Gen Virol. 1977;36:59-74.

Greber UF, Suomalainen M, Stidwill RP, Boucke K, Ebersold MW, Helenius A. The role of the nuclear pore complex in adenovirus DNA entry. EMBO J. 1997;16:59986007.

Hacein-Bey-Abina S, Von KC, Schmidt M, McCormack MP, Wulffraat N, Leboulch P, et al. LMO2-associated clonal T cell proliferation in two patients after gene therapy for SCID-X1. Science. 2003;302:415-9.

Harding TC, Geddes BJ, Noel JD, Murphy D, Uney JB. Tetracycline-regulated transgene expression in hippocampal neurones following transfection with adenoviral vectors. J Neurochem. 1997;69:2620-3.

Harding TC, Geddes BJ, Murphy D, Knight D, Uney JB. Switching transgene expression in the brain using an adenoviral tetracycline-regulatable system. Nat Biotechnol. 1998;16:553-5.

Horwood NJ, Smith C, Andreakos E, Quattrocchi E, Brennan F, Feldmann M, et al. High efficiency gene transfer into nontransformed cells: utility for studying gene regulation and analysis of potential therapeutic targets. Arthritis Research and Therapy. 2002;4(suppl 3):S215-225.

Havenga MJ, Lemckert AA, Ophorst OJ, van MM, Germeraad WT, Grimbergen J, et al. Exploiting the natural diversity in adenovirus tropism for therapy and prevention of disease. J Virol. 2002;76:4612-20.

He TC, Zhou S, da Costa LT, Yu J, Kinzler KW, Vogelstein B. A simplified system for generating recombinant adenoviruses. Proc Natl Acad Sci USA. 1998;95:2509-14.

Heinzinger NK, Bukinsky MI, Haggerty SA, Ragland AM, Kewalramani V, Lee MA, et al. The Vpr protein of human immunodeficiency virus type 1 influences nuclear localization of viral nucleic acids in nondividing host cells. Proc Natl Acad Sci USA. 1994;91:7311-5.

Hermens WT, Verhaagen J. Viral vectors, tools for gene transfer in the nervous system. Prog Neurobiol. 1998;55:399-432. 
Hermonat PL, Muzyczka N. Use of adeno-associated virus as a mammalian DNA cloning vector: transduction of neomycin resistance into mammalian tissue culture cells. Proc Natl Acad Sci USA. 1984;81:6466-70.

Ho DY, Mocarski ES. Beta-galactosidase as a marker in the peripheral and neural tissues of the herpes simplex virusinfected mouse. Virology. 1988;167:279-83.

Ho DY, Mocarski ES. Herpes simplex virus latent RNA (LAT) is not required for latent infection in the mouse. Proc Natl Acad Sci USA. 1989;86:7596-600.

Horwitz MS. Function of adenovirus E3 proteins and their interactions with immunoregulatory cell proteins. J Gene Med. 2004;6(Suppl 1):S172-83.

Howarth JL, Kelly S, Keasey MP, Glover CP, Lee YB, Mitrophanous K, et al. Hsp40 molecules that target to the ubiquitin-proteasome system decrease inclusion formation in models of polyglutamine disease. Molec Ther. 2007; 15:1100-5.

Howarth JL, Glover CP, Uney JB. HSP70 interacting protein prevents the accumulation of inclusions in polyglutamine disease. J Neurochem. 2009;108:945-51.

Jakobsson J, Ericson C, Jansson M, Bjork E, Lundberg C. Targeted transgene expression in rat brain using lentiviral vectors. J Neurosci Res. 2003;73:876-85.

Johnston JC, Gasmi M, Lim LE, Elder JH, Yee JK, Jolly DJ, et al. Minimum requirements for efficient transduction of dividing and nondividing cells by feline immunodeficiency virus vectors. J Virol. 1999;73:4991-5000.

Kafri T, van PH, Ouyang L, Gage FH, Verma IM. A packaging cell line for lentivirus vectors. J Virol. 1999;73:576-84.

Kafri T, van PH, Gage FH, Verma IM. Lentiviral vectors: regulated gene expression. Mol Ther. 2000;1:516-21.

Kang Y, Stein CS, Heth JA, Sinn PL, Penisten AK, Staber PD, et al. In vivo gene transfer using a nonprimate lentiviral vector pseudotyped with Ross River virus glycoproteins. J Virol. 2002;76:9378-88.

Kay MA, Glorioso JC, Naldini L. Viral vectors for gene therapy: the art of turning infectious agents into vehicles of therapeutics. Nat Med. 2001;7:33-40.

Kim VN, Mitrophanous K, Kingsman SM, Kingsman AJ. Minimal requirement for a lentivirus vector based on human immunodeficiency virus type 1. J Virol. 1998;72: 811-6.

Knaan-Shanzer S, Van DV, Havenga IMJ, Lemckert AA, De Vries AA, Valerio D. Highly efficient targeted transduction of undifferentiated human hematopoietic cells by adenoviral vectors displaying fiber knobs of subgroup B. Hum Gene Ther. 2001;12:1989-2005.

Kobinger GP, Weiner DJ, Yu QC, Wilson JM. Filoviruspseudotyped lentiviral vector can efficiently and stably transduce airway epithelia in vivo. Nat Biotechnol. 2001;19:225-30.

Koczot FJ, Carter BJ, Garon CF, Rose JA. Self-complementarity of terminal sequences within plus or minus strands of adenovirus-associated virus DNA. Proc Natl Acad Sci USA. 1973;70:215-9.

Kofron MD, Laurencin CT. Bone tissue engineering by gene delivery. Adv Drug Deliv Rev. 2006;58:555-76.

Kreppel F, Kochanek S. Modification of adenovirus gene transfer vectors with synthetic polymers: a scientific review and technical guide. Molec Ther. 2008;16:16-29.
Larochelle N, Lochmuller H, Zhao J, Jani A, Hallauer P, Hastings $\mathrm{KE}$, et al. Efficient muscle-specific transgene expression after adenovirus-mediated gene transfer in mice using a $1.35 \mathrm{~kb}$ muscle creatine kinase promoter/enhancer. Gene Ther. 1997;4:465-72.

Lee YB, Cosgrave AS, Glover CP, Bienemann A, Heywood D, Hobson RJ, et al. Increased utility in the CNS of a powerful neuron-specific tetracycline-regulatable adenoviral system developed using a post-transcriptional enhancer. J Gene Med. 2005;7:576-83.

Lemckert AA, Grimbergen J, Smits S, Hartkoorn E, Holterman L, Berkhout B, et al. Generation of a novel replicationincompetent adenoviral vector derived from human adenovirus type 49: manufacture on PER.C6 cells, tropism and immunogenicity. J Gen Virol. 2006;87:2891-9.

Leopold PL, Kreitzer G, Miyazawa N, Rempel S, Pfister KK, Rodriguez-Boulan E, et al. Dynein- and microtubulemediated translocation of adenovirus serotype 5 occurs after endosomal lysis. Hum Gene Ther. 2000;11:151-65.

Leppard KN. E4 gene function in adenovirus, adenovirus vector and adeno-associated virus infections. J Gen Virol. 1997;78(Pt 9):2131-8.

Lewis PF, Emerman M. Passage through mitosis is required for oncoretroviruses but not for the human immunodeficiency virus. J Virol. 1994;68:510-6.

Li E, Brown SL, Stupack DG, Puente XS, Cheresh DA, Nemerow GR. Integrin alpha(v)beta1 is an adenovirus coreceptor. J Virol. 2001;75:5405-9.

Logan AC, Haas DL, Kafri T, Kohn DB. Integrated selfinactivating lentiviral vectors produce full-length genomic transcripts competent for encapsidation and integration. J Virol. 2004;78:8421-36.

Lu X, Humeau L, Slepushkin V, Binder G, Yu Q, Slepushkina $\mathrm{T}$, et al. Safe two-plasmid production for the first clinical lentivirus vector that achieves $>99 \%$ transduction in primary cells using a one-step protocol. J Gene Med. 2004;6:963-73.

MacKenzie TC, Kobinger GP, Louboutin JP, Radu A, Javazon EH, Sena-Esteves M, et al. Transduction of satellite cells after prenatal intramuscular administration of lentiviral vectors. J Gene Med. 2005;7:50-8.

Manilla P, Rebello T, Afable C, Lu X, Slepushkin V, Humeau LM, et al. Regulatory considerations for novel gene therapy products: a review of the process leading to the first clinical lentiviral vector. Hum Gene Ther. 2005;16:17-25.

Markert JM, Parker JN, Buchsbaum DJ, Grizzle WE, Gillespie GY, Whitley RJ. Oncolytic HSV-1 for the treatment of brain tumours. Herpes. 2006;13:66-71.

Marttila M, Persson D, Gustafsson D, Liszewski MK, Atkinson JP, Wadell G, et al. CD46 is a cellular receptor for all species B adenoviruses except types 3 and 7. J Virol. 2005; 79:14429-36.

Mathews MB, Shenk T. Adenovirus virus-associated RNA and translation control. J Virol. 1991;65:5657-62.

Mazarakis ND, Azzouz M, Rohll JB, Ellard FM, Wilkes FJ, Olsen AL, et al. Rabies virus glycoprotein pseudotyping of lentiviral vectors enables retrograde axonal transport and access to the nervous system after peripheral delivery. Hum Mol Genet. 2001;10:2109-21.

McCarty DM, Monahan PE, Samulski RJ. Self-complementary recombinant adeno-associated virus (scAAV) vectors 
promote efficient transduction independently of DNA synthesis. Gene Ther. 2001;8:1248-54.

Mebatsion T, Schnell MJ, Conzelmann KK. Mokola virus glycoprotein and chimeric proteins can replace rabies virus glycoprotein in the rescue of infectious defective rabies virus particles. J Virol. 1995;69:1444-51.

Mentel R, Dopping G, Wegner U, Seidel W, Liebermann H, Dohner L. Adenovirus-receptor interaction with human lymphocytes. J Med Virol. 1997;51:252-7.

Miletic H, Bruns M, Tsiakas K, Vogt B, Rezai R, Baum C, et al. Retroviral vectors pseudotyped with lymphocytic choriomeningitis virus. J Virol. 1999;73:6114-6.

Mitrophanous K, Yoon S, Rohll J, Patil D, Wilkes F, Kim V, et al. Stable gene transfer to the nervous system using a non-primate lentiviral vector. Gene Ther. 1999;6:180818.

Miyoshi H, Blomer U, Takahashi M, Gage FH, Verma IM. Development of a self-inactivating lentivirus vector. J Virol. 1998;72:8150-7.

Mizuguchi H, Kay MA. Efficient construction of a recombinant adenovirus vector by an improved in vitro ligation method. Hum Gene Ther. 1998;9:2577-83.

Mochizuki H, Schwartz JP, Tanaka K, Brady RO, Reiser J. High-titer human immunodeficiency virus type 1-based vector systems for gene delivery into nondividing cells. J Virol. 1998;72:8873-83.

Monahan PE, Samulski RJ. AAV vectors: is clinical success on the horizon? Gene Ther. 2000;7:24-30.

Morizono K, Bristol G, Xie YM, Kung SK, Chen IS. Antibodydirected targeting of retroviral vectors via cell surface antigens. J Virol. 2001;75:8016-20.

Morral N, O'Neal W, Zhou H, Langston C, Beaudet A. Immune responses to reporter proteins and high viral dose limit duration of expression with adenoviral vectors: comparison of E2a wild type and E2a deleted vectors. Hum Gene Ther. 1997;8:1275-86.

Morrison J, Briggs SS, Green N, Fisher K, Subr V, Ulbrich K, et al. Virotherapy of ovarian cancer with polymer-cloaked adenovirus retargeted to the epidermal growth factor receptor. Molec Ther. 2008;16:244-51.

Muruve DA. The innate immune response to adenovirus vectors. Hum Gene Ther. 2004;15:1157-66.

Muzyczka N, Warrington KH Jr. Custom adeno-associated virus capsids: the next generation of recombinant vectors with novel tropism. Hum Gene Ther. 2005;16:408-16.

Naldini L, Blomer U, Gage FH, Trono D, Verma IM. Efficient transfer, integration, and sustained long-term expression of the transgene in adult rat brains injected with a lentiviral vector. Proc Natl Acad Sci USA. 1996;93:11382-8.

Nathanson JL, Yanagawa Y, Obata K, Callaway EM. Preferential labeling of inhibitory and excitatory cortical neurons by endogenous tropism of adeno-associated virus and lentivirus vectors. Neuroscience. 2009;161:441-50.

Nemerow GR. Cell receptors involved in adenovirus entry. Virology. 2000;274:1-4.

Nettelbeck DM. Cellular genetic tools to control oncolytic adenoviruses for virotherapy of cancer. J Mol Med. 2008;86:363-77.

Nevins JR. Mechanism of activation of early viral transcription by the adenovirus E1A gene product. Cell. 1981;26:21320.
Ni TH, McDonald WF, Zolotukhin I, Melendy T, Waga S, Stillman B, et al. Cellular proteins required for adenoassociated virus DNA replication in the absence of adenovirus coinfection. J Virol. 1998;72:2777-87.

Nicklin SA, Von Seggern DJ, Work LM, Pek DC, Dominiczak AF, Nemerow GR, et al. Ablating adenovirus type 5 fiberCAR binding and HI loop insertion of the SIGYPLP peptide generate an endothelial cell-selective adenovirus. Molec Ther. 2001;4:534-42.

Okada N, Saito T, Masunaga Y, Tsukada Y, Nakagawa S, Mizuguchi $\mathrm{H}$, et al. Efficient antigen gene transduction using Arg-Gly-Asp fiber-mutant adenovirus vectors can potentiate antitumor vaccine efficacy and maturation of murine dendritic cells. Cancer Res. 2001;61:7913-9.

Olsen JC. Gene transfer vectors derived from equine infectious anemia virus. Gene Ther. 1998;5:1481-7.

O'Rourke JP, Newbound GC, Kohn DB, Olsen JC, Bunnell BA. Comparison of gene transfer efficiencies and gene expression levels achieved with equine infectious anemia virusand human immunodeficiency virus type 1-derived lentivirus vectors. J Virol. 2002;76:1510-5.

Pacak CA, Sakai Y, Thattaliyath BD, Mah CS, Byrne BJ. Tissue specific promoters improve specificity of AAV9 mediated transgene expression following intra-vascular gene delivery in neonatal mice. Genet Vaccines Ther. 2008;6:13.

Pacchia AL, Adelson ME, Kaul M, Ron Y, Dougherty JP. An inducible packaging cell system for safe, efficient lentiviral vector production in the absence of HIV-1 accessory proteins. Virology. 2001;282:77-86.

Palmer DJ, Ng P. Helper-dependent adenoviral vectors for gene therapy. Hum Gene Ther. 2005;16:1-16.

Parker AL, Waddington SN, Nicol CG, Shayakhmetov DM, Buckley SM, Denby L, et al. Multiple vitamin K-dependent coagulation zymogens promote adenovirus-mediated gene delivery to hepatocytes. Blood. 2006;108:2554-61.

Parks RJ, Chen L, Anton M, Sankar U, Rudnicki MA, Graham FL. A helper-dependent adenovirus vector system: removal of helper virus by Cre-mediated excision of the viral packaging signal. Proc Natl Acad Sci USA. 1996;93:13565-70.

Parrott MB, Adams KE, Mercier GT, Mok H, Campos SK, Barry MA. Metabolically biotinylated adenovirus for cell targeting, ligand screening, and vector purification. Molec Ther. 2003;8:688-700.

Peel AL, Zolotukhin S, Schrimsher GW, Muzyczka N, Reier PJ. Efficient transduction of green fluorescent protein in spinal cord neurons using adeno-associated virus vectors containing cell type-specific promoters. Gene Ther. 1997;4:16-24.

Phillips JE, Gersbach CA, Garcia AJ. Virus-based gene therapy strategies for bone regeneration. Biomaterials. 2007;28:211-29.

Poeschla EM, Wong-Staal F, Looney DJ. Efficient transduction of nondividing human cells by feline immunodeficiency virus lentiviral vectors. Nat Med. 1998;4:354-7.

Power AT, Bell JC. Cell-based delivery of oncolytic viruses: a new strategic alliance for a biological strike against cancer. Molec Ther. 2007;15:660-5.

Poznansky M, Lever A, Bergeron L, Haseltine W, Sodroski J. Gene transfer into human lymphocytes by a defective human immunodeficiency virus type 1 vector. J Virol. 1991;65:532-6. 
Qian Z, Haessler M, Lemos JA, Arsenault JR, Aguirre JE, Gilbert JR, et al. Targeting vascular injury using Hantavirus-pseudotyped lentiviral vectors. Molec Ther. 2006;13:694-704.

Ralph GS, Bienemann A, Harding TC, Hopton M, Henley J, Uney JB. Targeting of tetracycline-regulatable transgene expression specifically to neuronal and glial cell populations using adenoviral vectors. NeuroReport. 2000;11: 2051-5.

Rea D, Havenga MJ, van Den AM, Sutmuller RP, Lemckert A, Hoeben RC, et al. Highly efficient transduction of human monocyte-derived dendritic cells with subgroup B fibermodified adenovirus vectors enhances transgene-encoded antigen presentation to cytotoxic $\mathrm{T}$ cells. J Immunol. 2001;166:5236-44.

Reiser J, Harmison G, Kluepfel-Stahl S, Brady RO, Karlsson S, Schubert M. Transduction of nondividing cells using pseudotyped defective high-titer HIV type 1 particles. Proc Natl Acad Sci USA. 1996;93:15266-71.

Reynolds PN, Nicklin SA, Kaliberova L, Boatman BG, Grizzle WE, Balyasnikova IV, et al. Combined transductional and transcriptional targeting improves the specificity of transgene expression in vivo. Nat Biotechnol. 2001;19: 838-42.

Roe T, Reynolds TC, Yu G, Brown PO. Integration of murine leukemia virus DNA depends on mitosis. EMBO J. 1993;12:2099-108.

Roelvink PW, Lizonova A, Lee JG, Li Y, Bergelson JM, Finberg RW, et al. The coxsackievirus-adenovirus receptor protein can function as a cellular attachment protein for adenovirus serotypes from subgroups A, C, D, E, and F. J Virol. 1998;72:7909-15.

Russell WC. Update on adenovirus and its vectors. J Gen Virol. 2000;81:2573-604.

Saenz DT, Poeschla EM. FIV: from lentivirus to lentivector. J Gene Med. 2004;6(Suppl 1):S95-104.

Sailaja G, HogenEsch H, North A, Hays J, Mittal SK. Encapsulation of recombinant adenovirus into alginate microspheres circumvents vector-specific immune response. Gene Ther. 2002;9:1722-9.

Sakurai F, Kawabata K, Koizumi N, Inoue N, Okabe M, Yamaguchi $\mathrm{T}$, et al. Adenovirus serotype 35 vectormediated transduction into human CD46-transgenic mice. Gene Ther. 2006;13:1118-26.

Salone B, Martina Y, Piersanti S, Cundari E, Cherubini G, Franqueville L, et al. Integrin alpha3betal is an alternative cellular receptor for adenovirus serotype 5. J Virol. 2003;77:13448-54.

Sanders DA. Ebola virus glycoproteins: guidance devices for targeting gene therapy vectors. Expert Opin Biol Ther. 2004;4:329-36.

Schaack J, Bennett ML, Colbert JD, Torres AV, Clayton GH, Ornelles D, et al. E1A and E1B proteins inhibit inflammation induced by adenovirus. Proc Natl Acad Sci USA. 2004;101:3124-9.

Schiedner G, Morral N, Parks RJ, Wu Y, Koopmans SC, Langston $\mathrm{C}$, et al. Genomic DNA transfer with a high-capacity adenovirus vector results in improved in vivo gene expression and decreased toxicity. Nat Genet. 1998;18:180-3.

Schiedner G, Hertel S, Johnston M, Biermann V, Dries V, Kochanek S. Variables affecting in vivo performance of high-capacity adenovirus vectors. J Virol. 2002;76: $1600-9$.

Schnepp BC, Jensen RL, Chen CL, Johnson PR, Clark KR. Characterization of adeno-associated virus genomes isolated from human tissues. J Virol. 2005;79:14793-803.

Segerman A, Arnberg N, Erikson A, Lindman K, Wadell G. There are two different species $\mathrm{B}$ adenovirus receptors: sBAR, common to species B1 and B2 adenoviruses, and SB2AR, exclusively used by species B2 adenoviruses. J Virol. 2003a;77:1157-62.

Segerman A, Atkinson JP, Marttila M, Dennerquist V, Wadell G, Arnberg N. Adenovirus type 11 uses CD46 as a cellular receptor. J Virol. 2003b;77:9183-91.

Sharma A, Li X, Bangari DS, Mittal SK. Adenovirus receptors and their implications in gene delivery. Virus Res. 2009;143:184-94.

Shevtsova Z, Malik JM, Michel U, Bahr M, Kugler S. Promoters and serotypes: targeting of adeno-associated virus vectors for gene transfer in the rat central nervous system in vitro and in vivo. Exp Physiol. 2005;90:53-9.

Shi W, Arnold GS, Bartlett JS. Insertional mutagenesis of the adeno-associated virus type 2 (AAV2) capsid gene and generation of AAV2 vectors targeted to alternative cellsurface receptors. Hum Gene Ther. 2001;12:1697-711.

Shimada T, Fujii H, Mitsuya H, Nienhuis AW. Targeted and highly efficient gene transfer into $\mathrm{CD}^{+}$cells by a recombinant human immunodeficiency virus retroviral vector. J Clin Invest. 1991;88:1043-7.

Short JJ, Pereboev AV, Kawakami Y, Vasu C, Holterman MJ, Curiel DT. Adenovirus serotype 3 utilizes CD80 (B7.1) and CD86 (B7.2) as cellular attachment receptors. Virology. 2004;322:349-59.

Sims K, Ahmed Z, Gonzalez AM, Read ML, Cooper-Charles L, Berry M, et al. Targeting adenoviral transgene expression to neurons. Mol Cell Neurosci. 2008;39:411-7.

Sinn PL, Burnight ER, Shen H, Fan H, McCray PB Jr. Inclusion of Jaagsiekte sheep retrovirus proviral elements markedly increases lentivirus vector pseudotyping efficiency. Molec Ther. 2005;11:460-9.

Somia N, Verma IM. Gene therapy: trials and tribulations. Nat Rev Genet. 2000;1:91-9.

Song JJ, Lee B, Chang JW, Kim JH, Kwon YK, Lee H. Optimization of vesicular stomatitis virus-G pseudotyped feline immunodeficiency virus vector for minimized cytotoxicity with efficient gene transfer. Virus Res. 2003; 93:25-30.

Spergel JM, Chen-Kiang S. Interleukin 6 enhances a cellular activity that functionally substitutes for E1A protein in transactivation. Proc Natl Acad Sci USA. 1991;88:6472-6.

Spergel JM, Hsu W, Akira S, Thimmappaya B, Kishimoto T, Chen-Kiang S. NF-IL6, a member of the C/EBP family, regulates E1A-responsive promoters in the absence of E1A. J Virol. 1992;66:1021-30.

Staal FJ, Pike-Overzet K, Ng YY, van Dongen JJ. Sola dosis facit venenum. Leukemia in gene therapy trials: a question of vectors, inserts and dosage? Leukemia. 2008;22:184952 .

Staba MJ, Wickham TJ, Kovesdi I, Hallahan DE. Modifications of the fiber in adenovirus vectors increase tropism for malignant glioma models. Cancer Gene Ther. 2000;7:13-9. 
Stachler MD, Bartlett JS. Mosaic vectors comprised of modified AAV1 capsid proteins for efficient vector purification and targeting to vascular endothelial cells. Gene Ther. 2006;13:926-31.

Stehle T, Harrison SC. High-resolution structure of a polyomavirus VP1-oligosaccharide complex: implications for assembly and receptor binding. EMBO J. 1997;16:5139-48.

Stein LD. Human genome: end of the beginning. Nature. 2004;431:915-6.

Stewart PL, Fuller SD, Burnett RM. Difference imaging of adenovirus: bridging the resolution gap between X-ray crystallography and electron microscopy. EMBO J. 1993;12:2589-99.

Stewart PL, Chiu CY, Huang S, Muir T, Zhao Y, Chait B, et al. Cryo-EM visualization of an exposed RGD epitope on adenovirus that escapes antibody neutralization. EMBO J. 1997;16:1189-98.

Stieger K, Belbellaa B, Le GC, Moullier P, Rolling F. In vivo gene regulation using tetracycline-regulatable systems. Adv Drug Deliv Rev. 2009;61:527-41.

Stone D, Lieber A. New serotypes of adenoviral vectors. Curr Opin Mol Ther. 2006;8:423-31.

Tatsis N, Blejer A, Lasaro MO, Hensley SE, Cun A, Tesema L, et al. A CD46-binding chimpanzee adenovirus vector as a vaccine carrier. Molec Ther. 2007;15:608-17.

Terzi D, Zachariou V. Adeno-associated virus-mediated gene delivery approaches for the treatment of CNS disorders. Biotechnol J. 2008;3:1555-63.

Todo T. "Armed" oncolytic herpes simplex viruses for brain tumor therapy. Cell Adh Migr. 2008;2:208-13.

Tuve S, Wang H, Ware C, Liu Y, Gaggar A, Bernt K, et al. A new group $\mathrm{B}$ adenovirus receptor is expressed at high levels on human stem and tumor cells. J Virol. 2006;80:12109-20.

Verma IM, Weitzman MD. Gene therapy: twenty-first century medicine. Annu Rev Biochem. 2005;74:711-38.

Vigna E, Naldini L. Lentiviral vectors: excellent tools for experimental gene transfer and promising candidates for gene therapy. J Gene Med. 2000;2:308-16.

Virta S, Rapola J, Jalanko A, Laine M. Use of nonviral promoters in adenovirus-mediated gene therapy: reduction of lysosomal storage in the aspartylglucosaminuria mouse. J Gene Med. 2006;8:699-706.

Vogel R, Amar L, Thi AD, Saillour P, Mallet J. A single lentivirus vector mediates doxycycline-regulated expression of transgenes in the brain. Hum Gene Ther. 2004;15:157-65.

Waddington SN, McVey JH, Bhella D, Parker AL, Barker K, Atoda $\mathrm{H}$, et al. Adenovirus serotype 5 hexon mediates liver gene transfer. Cell. 2008;132:397-409.

Wadell G, Hammarskjold ML, Winberg G, Varsanyi TM, Sundell G. Genetic variability of adenoviruses. Ann N Y Acad Sci. 1980;354:16-42.

Wang K, Huang S, Kapoor-Munshi A, Nemerow G. Adenovirus internalization and infection require dynamin. J Virol. 1998;72:3455-8.

Wang Z, Ma HI, Li J, Sun L, Zhang J, Xiao X. Rapid and highly efficient transduction by double-stranded adenoassociated virus vectors in vitro and in vivo. Gene Ther. 2003;10:2105-11.

Watson DJ, Kobinger GP, Passini MA, Wilson JM, Wolfe JH. Targeted transduction patterns in the mouse brain by lentivirus vectors pseudotyped with VSV, Ebola, Mokola, LCMV, or MuLV envelope proteins. Molec Ther. 2002; 5:528-37.

Weis W, Brown JH, Cusack S, Paulson JC, Skehel JJ, Wiley DC. Structure of the influenza virus haemagglutinin complexed with its receptor, sialic acid. Nature. 1988; 333:426-31.

White SJ, Nicklin SA, Buning H, Brosnan MJ, Leike K, Papadakis ED, et al. Targeted gene delivery to vascular tissue in vivo by tropism-modified adeno-associated virus vectors. Circulation. 2004;109:513-9.

Wickham TJ, Mathias P, Cheresh DA, Nemerow GR. Integrins alpha $\mathrm{v}$ beta 3 and alpha $\mathrm{v}$ beta 5 promote adenovirus internalization but not virus attachment. Cell. 1993;73:309-19.

Wickham TJ, Tzeng E, Shears LL, Roelvink PW, Li Y, Lee $\mathrm{GM}$, et al. Increased in vitro and in vivo gene transfer by adenovirus vectors containing chimeric fiber proteins. J Virol. 1997;71:8221-9.

Wilson JM. Adenoviruses as gene-delivery vehicles. N Engl J Med. 1996;334:1185-7.

Wolff JA, Fisher LJ, Xu L, Jinnah HA, Langlais PJ, Iuvone PM, et al. Grafting fibroblasts genetically modified to produce L-dopa in a rat model of Parkinson disease. Proc Natl Acad Sci USA. 1989;86: 9011-4.

Wong LF, Azzouz M, Walmsley LE, Askham Z, Wilkes FJ, Mitrophanous KA, et al. Transduction patterns of pseudotyped lentiviral vectors in the nervous system. Molec Ther. 2004;9:101-11.

Wong LF, Ralph GS, Walmsley LE, Bienemann AS, Parham S, Kingsman SM, et al. Lentiviral-mediated delivery of Bcl-2 or GDNF protects against excitotoxicity in the rat hippocampus. Molec Ther. 2005;11:8995.

Wright JF, Qu G, Tang C, Sommer JM. Recombinant adenoassociated virus: formulation challenges and strategies for a gene therapy vector. Curr Opin Drug Discov Dev. 2003;6:174-8.

Wu E, Trauger SA, Pache L, Mullen TM, Von Seggern DJ, Siuzdak G, et al. Membrane cofactor protein is a receptor for adenoviruses associated with epidemic keratoconjunctivitis. J Virol. 2004;78:3897-905.

$\mathrm{Xu}$ K, Ma H, McCown TJ, Verma IM, Kafri T. Generation of a stable cell line producing high-titer self-inactivating lentiviral vectors. Molec Ther. 2001;3:97-104.

Yanez-Munoz RJ, Balaggan KS, MacNeil A, Howe SJ, Schmidt M, Smith AJ, et al. Effective gene therapy with nonintegrating lentiviral vectors. Nat Med. 2006;12:348-53.

Yang Y, Nunes FA, Berencsi K, Furth EE, Gonczol E, Wilson JM. Cellular immunity to viral antigens limits E1-deleted adenoviruses for gene therapy. Proc Natl Acad Sci USA. 1994a;91:4407-11.

Yang Y, Nunes FA, Berencsi K, Gonczol E, Engelhardt JF, Wilson JM. Inactivation of E2a in recombinant adenoviruses improves the prospect for gene therapy in cystic fibrosis. Nat Genet. 1994b;7:362-9.

Yang Y, Li Q, Ertl HC, Wilson JM. Cellular and humoral immune responses to viral antigens create barriers to lungdirected gene therapy with recombinant adenoviruses. J Virol. 1995;69:2004-15. 
Yang GS, Schmidt M, Yan Z, Lindbloom JD, Harding TC, Donahue BA, et al. Virus-mediated transduction of murine retina with adeno-associated virus: effects of viral capsid and genome size. J Virol. 2002;76:7651-60.

Zou L, Zhou H, Pastore L, Yang K. Prolonged transgene expression mediated by a helper-dependent adenoviral vector (hdAd) in the central nervous system. Molec Ther. 2000;2:105-13.
Zufferey R, Nagy D, Mandel RJ, Naldini L, Trono D. Multiply attenuated lentiviral vector achieves efficient gene delivery in vivo. Nat Biotechnol. 1997;15:871-5.

Zufferey R, Donello JE, Trono D, Hope TJ. Woodchuck hepatitis virus posttranscriptional regulatory element enhances expression of transgenes delivered by retroviral vectors. J Virol. 1999;73:2886-92. 